\title{
Penggunaan metode PPP (Presentation, Practice and Production) untuk Meningkatkan Hasil Belajar Siswa pada Mata Pelajaran Bahasa Inggris Materi Interaksi Pengandaian Diikuti Oleh Perintah/Saran di SMAN 4 Kota Bima Kelas XII MIPA.1 Semester Genap Tahun Pelajaran 2019/2020
}

\author{
Faisal Hasibuan \\ SMA Negeri 4 Kota Bima, Kota Bima, Indonesia \\ *Coresponding Author: sanifalfaris45@gmail.com \\ Dikirim: 19-08-2021; Direvisi: 24-10-2021; Diterima: 25-10-2021
}

\begin{abstract}
Abstrak: Pelaksanaan pembelajaran pra-sklus prestasi belajar siswa rendah, hal ini ditunjukkan dengan rendahnya rata-rata nilai formatif tes siswa yakni 64 dengan ketuntasan klasikal $70 \%$. Hal ini masih dibawah indikator kinerja yang ditentukan yakni rata-rata $\geq 75$ dengan ketuntasan klasikal $\geq 85 \%$. Berdasarkan latar belakang masalah tersebut peneliti merumuskan masalah sebagai berikut: Bagaimana penggunaan metode PPP (Presentation, Pratice and Production) untuk meningkatkan hasil belajar siswa pada mata pelajaran Bahasa Inggris materi interaksi pengandaian diikuti oleh perintah/saran di SMA Negeri 4 Kota Bima kelas XII MIPA.1 semester genap tahun pelajaran 2019/2020. Tujuan Penelitian: 1) Mendeskripsikan penggunaan metode PPP (presentation, practice and production) untuk meningkatkan hasil belajar siswa pada mata pelajaran Bahasa Inggris materi interaksi pengandaian diikuti oleh perintah/saran di SMA Negeri 4 Kota Bima kelas XII MIPA.1 semester genap tahun pelajaran 2019/2020. 2) Mendeskripsikan dan menganalisis dampak penggunaan metode PPP (presentation, practice and production) untuk meningkatkan hasil belajar siswa pada mata pelajaran Bahasa Inggris materi interaksi pengandaian diikuti oleh perintah/saran di SMAN 4 Kota Bima kelas XII MIPA.1 semester genap tahun pelajaran 2019/2020. Penelitian dilaksanakan dalam 2 (dua) siklus. Siklus I dari tanggal 24 Maret 2020 sampai dengan tanggal 30 Maret 2020 dan siklus II dilaksanakan tanggal 05 April 2020 sampai dengan 13 April 2020. Subyek penelitian adalah siswa kelas XII MIPA-1 SMAN 1 Bolo dengan jumlah siswa 30, terdiri dari 14 orang laki-laki dan 16 orang perempuan. Teknik pengumpulan data meliputi pengamatan, dokumen dan tes. Peningkatan prestasi belajar siswa ini dapat dibandingkan dari hasil tes pra-perbaikan. Teknik pengumpulan data meliputi pengamatan, dokumen dan tes. Peningkatan hasil belajar siswa ini dapat dibandingkan dari hasil tes pra-perbaikan. Siklus I, prestasi belajar siswa rata-rata 68.00 (+4.00), Persentase ketuntasan $75.00 \%$, Persentase ini masih dibawah indikator kinerja yakni $\geq 85 \%$. Dari sisi prestasi belajar siklus I (pertama) belum berhasil sehingga dilanjutkan pada sikus II. Skor kinerja guru kompetensi guru dalam perencanaan kegiatan pembelajaran yang mendidik pada siklus I 90,90\%. Skor kinerja guru kompetensi guru dalam pelaksanaan pembelajaran kegiatan pembelajaran yang mendidik pada siklus I 90,77. Dengan demikian dari sisi kinerja guru siklus I belum mencapai indikator kinerja yang ditetapkan yakni $\geq 91 \%$. Siklus II, prestasi belajar siswa rata-rata 78,00 (+10.00) dengan ketuntasan belajar klasikal $88,00 \%$ (+13). Dengan perbaikan proses pada pembelajaran maka siklus II berhasil mencapai indikator yang ditetapkan yakni rata-rata $\geq 75$ dan persentase ketuntasan $\geq 85 \%$. Dari sisi prestasi belajar siklus II (kedua) telah berhasil. Skor kinerja guru kompetensi guru dalam perencanaan kegiatan pembelajaran yang mendidik pada siklus II 92,80\% semuanya deskriptor seluruhnya dilaksanakan (seluruhnya terpenuhi). Skor kinerja guru kompetensi guru dalam pelaksanaan pembelajaran kegiatan pembelajaran yang mendidik pada siklus II 91,78. Dengan demikian dari sisi kinerja guru siklus II berhasil mencapai indikator kinerja
\end{abstract}

@2021 JPPI (https://jurnal.bimaberilmu.com/index.php/jppi) 264

Ciptaan disebarluaskan di bawah Lisensi Creative Commons Atribusi 4.0 Internasional 
yang ditetapkan yakni $\geq 91 \%$. Peningkatkan Prestasi belajar siswa, disebabkan oleh peningkatan aktivitas pembelajaran siswa, interaksi guru dan siswa dalam proses pembelajaran di kelas dengan mengimplementasikan teknik pembelajaran PPP (presentation, practice and production) yang dilaksanakan guru, sesuai dengan nilai kinerja guru. Dengan demikian setelah pelaksanaan perbaikan pembelajaran sampai siklus II, telah mencapai indikator kinerja yang ditetapkan, dan penelitian dianggap telah berhasil.

Kata Kunci: Kemampuan menulis; metode PPP (presentation, practice and production)

Abstract: The implementation of pre-cycle learning of students' learning achievement is low, this is indicated by the low average formative test scores of students, namely 64 with classical completeness of $70 \%$. This is still below the specified performance indicator, which is an average of 75 with classical completeness of $85 \%$. Based on the background of the problem, the researcher formulates the problem as follows: How to use the PPP (Presentation, Pratice and Production) method to improve student learning outcomes in English subject matter of presuppositional interaction followed by orders/suggestions at SMA Negeri 4 Kota Bima, class XII MIPA. 1 even semester of the 2019/2020 school year. Research Objectives: 1) Describe the use of the PPP (presentation, practice and production) method to improve student learning outcomes in English subject matter of presuppositional interaction followed by orders/suggestions at SMA Negeri 4 Kota Bima class XII MIPA.1 even semester of the 2019 school year /2020. 2) Describe and analyze the impact of using the PPP method (presentation, practice and production) to improve student learning outcomes in English subjects subject to presuppositional interaction followed by orders/suggestions at SMAN 4 Kota Bima class XII MIPA.1 even semester of the 2019 academic year/ 2020. The research was carried out in 2 (two) cycles. Cycle I from March 24, 2020 to March 30, 2020 and cycle II was held from April 05, 2020 to April 13, 2020. The subjects of the study were students of class XII MIPA-1 SMAN 1 Bolo with a total of 30 students, consisting of 14 boys. male and 16 female. Data collection techniques include observations, documents and tests. This increase in student achievement can be compared from the results of the preimprovement test. Data collection techniques include observations, documents and tests. This improvement in student learning outcomes can be compared from the results of the preimprovement test. Cycle I, the average student learning achievement is $68.00(+4.00)$, the percentage of completeness is $75.00 \%$, this percentage is still below the performance indicator, namely $85 \%$. In terms of learning achievement, cycle I (first) has not been successful, so it is continued in cycle II. The teacher's performance score of teacher competence in planning learning activities that educate in the first cycle is $90.90 \%$. The teacher's performance score of teacher competence in the implementation of learning learning activities that educate in the first cycle is 90.77. Thus, in terms of teacher performance in cycle I, the performance indicators have not yet reached the specified $91 \%$. Cycle II, the average student learning achievement is $78.00(+10.00)$ with classical learning completeness $88.00 \%(+13)$. With the improvement of the learning process, the second cycle succeeded in achieving the specified indicators, namely an average of 75 and a percentage of completeness $85 \%$. In terms of learning achievement, cycle II (second) has been successful. The teacher's performance score of teacher competence in planning learning activities that educate in cycle II is $92.80 \%$, all descriptors are all implemented (all fulfilled). The teacher's performance score of teacher competence in the implementation of learning activities that educate in the second cycle is 91.78 . Thus, in terms of teacher performance, cycle II succeeded in achieving the specified performance indicator, namely $91 \%$. Improving student learning achievement, is caused by an increase in student learning activities, teacher and student interactions in the learning process in the classroom by implementing PPP (presentation, practice and production) learning techniques carried out by teachers, according to the teacher's performance value. Thus, after the implementation of learning improvements

@2021 JPPI (https://jurnal.bimaberilmu.com/index.php/jppi) 
up to cycle II, the performance indicators have been achieved, and the research is considered successful.

Keywords: Writing ability; PPP method (presentation, practice and production)

\section{PENDAHULUAN}

Kurikulum 2013 Seperti yang dikutip oleh S. Nasution, B. Othanel Smith, W.O. Stanley, dan J. Harlan Shores memandang kurikulum sebagai "a sequence of potential experiences set up in the school for the purpose of disciplining children and youth in group ways of thinking and acting.

Kurikulum sebagai sejumlah pengalaman yang secara potensial dapat diberikan kepada anak dan pemuda, agar mereka dapat berpikir dan berbuat sesuai dengan masyarakatnya. Sedangkan kurikulum yang didefinisikan oleh Beauchamp (dalam Sa'dun, 2010) bahwa "a curriculum is a written document which may contain many ingredients, but basically it is a plan for the education of people during theirenrolment in given school". Kurikulum adalah dokumen tertulis yang berisi bahan-bahan, tetapi pada dasarnya, ia merupakan rencana pendidikan bagi orangorang selama mereka mengikuti pendidikan yang diberikan di sekolah.

Definisi yang senada dalam pedoman pengembangan kurikulum 2013 yaitu Undang-Undang Nomor 20 Tahun 2003 tentang Sistem Pendidikan Nasional yang menyebutkan bahwa kurikulum adalah seperangkat rencana dan pengaturan mengenai tujuan, isi, dan bahan pelajaran serta cara yang digunakan sebagai pedoman penyelenggaraan kegiatan pembelajaran untuk mencapai tujuan pendidikan tertentu.

Peran guru profesional dalam pembelajaran sangat penting sebagai kunci keberhasilan belajar peserta didik dan mengahasilkan lulusan yang berkualitas. Guru profesional adalah guru yang kompeten dalam membangun dan mengembangkan proses pembelajaran yang baik dan efektif sehingga dapat menghasilkan peserta didik yang pintar dan pendidikan yang berkualitas. Hal tersebut menjadikan kualitas pembelajaran sebagai komponen yang menjadi fokus perhatian pemerintah pusat maupun pemerintah daerah dalam meningkatkan mutu pendidikan terutama menyangkut kualitas lulusan peserta didik.

Dalam pembelajaran Bahasa Inggris sebagai second language, melatih kemampuan menulis (writting) sebagai sebuah productive skill sering dianggap sebagai salah satu aspek yang paling menantang, dan kesulitan-kesulitan dalam menulis (writting) berbagai jenis teks yang berbeda bersumber dari fakta bahwa para pembelajar harus memahami fitur-fitur bahasa (linguistic features) dari berbagai jenis teks tersebut (Hyland, 2003b). Selain dari pada memahami linguistic features dari teks, pembelajar dihadapkan pula pada tantangan yang dirasa lebih berat, yaitu dapat secara kohesif menulis (writting) berdasarkan pada aturan-aturan baku (conventions) yang specific dari teks (Flowerdew, 2002). Terlebih dalam pembelajaran Bahasa Inggris, aturan-aturan baku dari teks (rhetorical conventions), seperti structure, style, organization.

Untuk dapat mencapai tujuan pembelajaran kemampuan menulis (writting) dalam Bahasa Inggris sebagai second language, yaitu menghasilkan teks yang tidak hanya berterima secara bahasa, namun juga secara retorik (linguistically and rhetorically appropriate), pembelajar seyogyanya diberikan pemahaman akan kedua hal tersebut, yaitu pemahaman struktur bahasa maupun konvensi dari teks 
tertentu. Dalam pembelajaran Bahasa Inggris, menulis (writting) merupakan salah satu kemampuan dasar yang diajarkan sejak di semester awal untuk memberi bekal kepada peserta didik dalam mengungkapkan ide-idenya secara tertulis.

Pada saat pelaksanaan pembelajaran pra siklus, ada permasalahan yang umum ditemui dalam pembelajaran menulis (writting) adalah walaupun peserta didik dapat menulis (writting) sebuah teks yang dapat dipahami (meaningful and communicative) oleh pembaca (audience), namun teks tersebut belum memenuhi kaidah struktur teks dalam bahasa target, yaitu Bahasa Inggris. Struktur yang tercermin dalam penulisan, misalnya recount text, masih mencerminkan struktur teks tersebut dalam Bahasa Indonesia. Hal ini tentu saja membuat tujuan pembelajaran tidak tercapai secara maksimal. Pada pembelajaran menulis (writting) dianggap sebagai hal yang penting (crucial), berdasarkan pada setidaknya dua hal. Pertama, peserta didik dituntut untuk menulis (writting) tes dalam Bahasa Inggris. Sehingga kemampuan menulis (writting) sesuai dengan kaidah penulisan dalam Bahasa Inggris wajib dimiliki. Kedua, peserta didik dipandang sebagai calon pendidik, sehingga diharapkan peserta didik dapat memahami pula metode pengajaran menulis (writting) yang dapat mengakomodasi kedua kebutuhan peserta didik dalam penguasaan kemahiran menulis (writting), yang kelak dapat diaplikasikan dalam proses pembelajaran yang akan mereka jalankan.

Berdasarkan pengamatan, khususnya pada pelajaran Menulis (writting) kelas XII MIPA-1, dalam menulis (writting) sebuah teks, peserta didik masih mengalami kendala dalam memahami kaidah penulisan suatu teks tertentu dan membedakan kaidah penulisan satu teks dengan yang lain. Dalam kaitannya dengan penggunaan struktur bahasa yang tepat untuk sebuah teks, masih terdapat ketidaksesuaian antara fitur bahasa yang seharusnya dan fitur bahasa yang digunakan oleh peserta didik. Misalnya, dalam menulis (writting) interaksi pengandaian diikuti oleh perintah/saran; struktur yang digunakan belum tepat.

Rendahnya prestasi belajar ditandai dengan tidak tercapainya indikator kinerja yang ditentukan oleh peneliti yakni prestasi belajar siswa rata-rata nilai formatif tes siswa yakni 64 dengan ketuntasan klasikal 70\%. Hal ini masih dibawah indikator kinerja yang ditentukan yakni rata-rata $\geq 75$ dengan ketuntasan klasikal $\geq 85 \%$. Demikian pula kinerja guru yang diukur dengan APKG 1 dan APKG 2 rendah. Nilai APKG 1, untuk perencanaan pembelajaran 91.00 dan APKG 2, pelaksanaan pembelajaran 90.00. Nilai ini dibawah indikator kinerja guru yang ditetapkan yakni APKG 1, untuk perencanaan pembelajaran 91.00 dan APKG 2, pelaksanaan pembelajaran 91.00.

Permasalahan pembelajaran yang dilakukan peneliti dalam pembelajaran menulis (writting) dapat diidentifikasi sebagai berikut:

a) Bahwa dalam menulis (writting) sebuah teks, peserta didik masih belum menggunakan kaidah penulisan, misalnya gaya bahasa dan struktur teks, yang sesuai dengan kaidah penulisan dalam bahasa Inggris.

b) Peserta didik belum memahami perbedaan karakteristik berbagai jenis text sehingga kemudian berakibat pada hasil tulisan yang belum optimal.

\section{KAJIAN TEORI}

\section{Kemampuan Menulis (writting)}


Dalam pembelajaran bahasa, setidaknya ada tiga pandangan terhadap menulis (writting). Pandangan pertama memposisikan menulis (writting) sebagai proses (menulis (writting) as a process). Dalam pandangan ini, kegiatan pembelajaran dimulai dengan latihan dan praktik menulis (writting) suatu hal (Collerson, 1988). Pandangan kedua memposisikan menulis (writting) sebagai sebuah fenomena sosial. Painter dan Martin (1986) menyatakan bahwa teks yang bermakna dalam kehidupan adalah teks yang dikonstruksikan secara bersama-sama. Pandangan lain mengenai menulis (writting) dikemukakan oleh Shilva (1990, dalam Hyland, 2003). Menulis (writting) dianggap sebagai sebuah produk yang dihasilkan dari pengetahuan gramatik dan leksikal seseorang.

\section{Menulis (writting) Sebagai Proses}

Collerson (1988) menyatakan bahwa menulis (writting) sebagai proses ditandai dengan adanya latihan menulis (writting) secara berulang-ulang. Repetisi ini disebut dengan rehearsal. Proses pembelajaran dengan model ini dilaksanakan dalam beberapa fase yang berbeda. Pada fase-fase tersebut, peserta didik diberikan kesempatan untuk merevisi, memperbaiki, dan melakukan proof reading pada tulisan yang dihasilkan. Dengan demikian, peserta didik dapat mendapatkan pemahaman mengenai genre teks yang dipelajari karena peserta didik diajarkan cara menulis (writting) teks dengan efektif.

\section{Menulis (writting) Sebagai Fenomena Sosial}

Pandangan ini diutarakan oleh Painter dan Martin (1986) yang menyatakan bahwa teks yang bermakna dikontruksikan secara bersama-sama oleh individuindividu. Dalam pembelajaran di kelas, peserta didik merekonstruksikan sebuah teks dengan bekerja secara kelompok. Peserta didik membangun pemahaman mengenai teks tersebut dari berdikusi dengan anggota kelompoknya. Guru berperan dengan memandudan proses diskusi yang dilakukan oleh peserta didik dalam proses pembelajaran. Oleh karena itu, proses menulis (writting) merupakan fenomena social karena proses ini melibatkan banyak pihak.

\section{Menulis (writting) Sebagai Sebuah Produk}

Harmer (2001) menyatakan bahwa menulis (writting) yang berorientasi sebagai produk berfokus pada tujuan menulis (writting) dan produk akhir atau karya yang dihasilkan. Argumen ini didukung oleh Shilva (1990, dalam Hyland, 2003) yang memandang bahwa menulis (writting) adalah hasil dari proses imitasi dan manipulasi model tulisan yang diberikan oleh guru. Karya dihasilkan oleh peserta didik adalah akumulasi pengetahuan gramatik dan leksikal yang dikonstruksikan menjadi sebuah teks yang bermakna.

\section{Pembelajaran Menulis (writting)}

Dalam pembelajaran bahasa Inggris sebagai bahasa kedua/asing (ESL/EFL), pembelajaran menulis (writting) sering dianggap sebagai proses yang kompleks. Hal ini disebabkan oleh setidaknya tiga hal. Pertama, kemampuan menulis (writting) merupakan akumulasi dari pengetahuan literasi dan teori-teori menulis (writting). Kedua, kegiatan pembelajaran perlu memberikan pemahaman mengenai perbedaan retorika antara bahasa ibu pembelajar dan bahasa asing. Ketiga, keterbatasan waktu 
pembelajaran membuat kegiatan pembelajaran sering tidak optimal karena proses menulis (writting) memerlukan waktu yang panjang.

Sesuai dengan penjelasan sebelumnya, pembelajaran menulis (writting), secara umum terbagi menjadi dua yaitu pembelajaran berorientasi proses dan produk. Harmer (2001) menyatakan bahwa perbedaan kedua jenis pembelajaran menulis (writting) tersebut adalah pada titik beratnya. Pembelajaran berbasis produk menitikberatkan pada produk akhirnya dan tujuan menulis (writting)nya. Sedangkan pembelajaran berbasis proses berorientasi pada tahap-tahap penulisan dari proses paling awal yaitu brainstorming sampai publishing.

Pada jenis pembelajaran menulis (writting) berbasis proses, pembelajar melewati beberapa proses dalam menghasilkan sebuah tulisan. Pada umumnya, proses tersebut merupakan pengembangan dari first draft menuju ke final draft. White and Arndt (1991) membagi proses menulis (writting) menjadi lima jenis yaitu drafting, structuring, reviewing, focusing, dan generating ideas and evaluation. Berbeda dengan White dan Arndt, Harmer (2001) menawarkan tahapan yang berbeda dalam proses pembelajaran menulis (writting) berbasis proses membagi tahap menulis (writting) menjadi pre-menulis (writting), drafting, editing, redrafting, dan publishing.

\section{PPP (presentation, practice and production) dan Pengajaran Menulis (writting)}

Selama beberapa dekade terakhir, pembelajaran menulis (writting) skill dalam konteks second language dikembangkan untuk meningkatkan kemahiran (proficiency) pembelajar dalam menulis (writting). Pada dekade 1970an dan sebagian besar dekade 1980an, para ahli tertarik lebih banyak pada peningkatan kemampuan linguistik pembelajar melalui kegiatan seperti perencanaan (planning), pembuatan draf (drafting), penyuntingan (editing) dan revisi (revision) (Badger \& White, 2000; Feez\& Joyce, 2002; Muncie, 2002). Selanjutnya, pada akhir 1980an dan sepanjang dekade 1990an, teori pengajaran menulis (writting) mulai beralih pada genre approach yang memandang menulis (writting) sebagai sebuah kegiatan yang bermakna dan memiliki tujuan (purposeful), dan fokus pada analisa konteks situasi dimana menulis (writting) tersebut berada (Atkinson, 2003; Hyland, 2003a, 2003b, 2007; Paltridge, 1996, 2000, 2001, 2002,2007).

\section{Teknik pembelajaran PPP (presentatiin, practice and production)}

Salah satu cara untuk meningkatkan kemampuan mengarang siswa adalah dengan menerapkan teknik PPP (presentation, practice and production), atau dalam bahasa Indoneisa presentasi, praktek, dan produksi. Tehnik ini dapat mendapat siswa menjadi aktif dalam proses dalam pembelajaran. Harmer (2001:80) Mendefenisikan bahwa presentasi, praktik, dan produksi adalah variasi pada audio-lingualisme dalam pengajaran berbasis inggris dan di tempat lain adalah prosedur yang paling sering di sebut sebagi PPP. Yang pertama adalah Presentasi dimana guru memulai pelajran dengan menyiapkan situasi, memilih atau memodelkan beberapa bahasa yang di butuhkan dalam situasi. resentasi dapat terdiri dari model kalimat, dialog pendek yang menggabarkan item sasaran, baik yang dapat di baca dari buku teks, dengar rekamannya atau di lakukan dengan guru. yang kedua adalah praktik dimana siswa mempraktikan bahasa baru dengan cara yang terkendali. Mereka menyusun kalimat atau dialoq dengan mengulang setelah guru atau rekaman itu, dalam paduan suara secara terpisah, sampai mereka dapat mengatakannya dengan benar. Yang terakhir 
adalah produksi dimna siswa didorong untuk menggunakan bahasa baru baik untuk tujuan dan makna bagi mereka sendiri atau dalam konteks yang sama di perkenalkan oleh guru.

Pollard (2008:22) menyatakan bahwa PPP PPP (presentation, practice and production), atau dalam bahasa Indoneisa presentasi, praktek, dan produksi. Ini adalah cara yang cukup tradisional untuk menyusun pelajaran yang populer sepanjang tahun 1980 an. Hal ini terbukti bermanfaat pada tingkat yang lebih rendah dan masih banyak menggunakan saat ini. Presentasi melibatkan, seperti namanya yaitu menyajikan sebuah kesebuah titik bahasa. Hal ini biasanya dilakukan oleh guru. Presentasi mungkin serupa dengan pendekatan audio-bahasa melalui penggunaan gambar dan di fokuskan pada pembelajaran. Hal itu juga bisa dicapai melalui penjelasan dan demontrasi. Praktik mengacu pada praktik pengendalian, ini melibatkan siswa yang menggunakan bahasa target dengan cara yang terkontrol. ini mungkin melibatkan latiahan, aktivitas tertulis dan berbicara terkontrol, dan pengulangan. Produksi mengacu pada praktik bebas dimana siswa menggunakan bahasa target dalam kalimat mereka sendiri. Mereka mungkin juga menggambungkan dengan bahasa lain yang mereka ketahui.

Berdasarkan defenisi diatas presentasi, praktik, dan produksi (PPP) sangat efektif untuk membuat siswa meningkatkan kemampuan dalam proses pembelajaran baik itu kemampuan mengarang, menulis maupun berbicara. Semakin sering siswa dalam melatih kemampuan mengarangnya maka siswa dapat menguasai penerapan bahasa yang baik dan efektif. Ide atau gagasan yang dimiliki oleh siswa sering kali tidak muncul ketika proses berfikir karena kurang adanya umpan balik sehinggga sering kali siswa menunggu dalam waktu yang lama untuk memunculkan ide yang ada dipikiran mereka. Melalui penerapan teknik PPP (Presentasi, Praktik, dan Produksi) siswa mulai membuka wawasan terhadap media yang diberikan. Hal ini dapat memotivasi siswa untuk meningkatkan kemampuan mengarang melalui media gambar. Siswa dapat menuangkan ide - ide baru untuk mendekskripsikan tema yang telah diberikan oleh guru. Siswa juga dapat membagi atau menyalurkan ide yang telah mereka dapatkan kepada teman sekelasnya.

Menurut Harmer (2001:80), ada tiga tahap penerapa teknik PPP (Presentasi, Praktek, dan Produksi) adalah sebagai berikut:

1. Presentasi

Presentasi di mulai dengan guru memperkenalkan materi kepada siswa. Guru menjelaskan secara detail aktivitas selanjutnya yang akan di lakukan oleh siswa. kemudian siswa harus memperhatikan secara seksama terhadap apa yang di jelaskan oleh guru.

2. Praktik

Praktek disini dimaksudkan sebagai latihan dimana siswa akan di beri aktivitas dan mempunyai banyak kesempatan untuk memperaktekkan aspek bahasa baru. Siswa akan mulai berdiskusi dengan teman kelompoknya dimana guru hanya memberikan bantuan yang terbatas. Guru juga memberikan dukungan yang dibutuhkan dan dorongan yang besar.

3. Produksi

Ini merupakan tahap akhir dari teknik PPP. Dalam tahap ini siswa akan menggunakan bahasa dalam konteks, dan dalam aktivitas yang disiapkan oleh guru 
yang akan memberikan bantuan minimal. Siswa akan mempresentasikan apa yang telah didiskusikan di depan kelas.

\section{Recount Text}

Dalam recount text siswa dituntut untuk membangun sebuah teks yang terorganisasi atau terstruktur yang dirangkai untuk menceritakan kejadian-kejadian pada masa lalu. Dengan kata lain, siswa menceritakan kejadian yang dialami kepada orang lain yang dapat diungkapkan melalui bentuk tulisan yang di dalamnya dituliskan kronologis peristiwa-peristiwa yang terjadi. Recount text adalah jenis teks yang berisi tentang pengalaman pribadi seseorang yang disampaikan secara terurut (Fadlun, 2011: 98).

Menurut Anderson \& Anderson, (1997:48) recount text bertujuan untuk memberikan gambaran kepada pembaca tentang sebuah peristiwa yang terjadi menurut waktu dan tempat kejadiannya yang difokuskan adalah kejadian yang ditulis secara berurutan. Terdapat tiga jenis recount text, yaitu (1) personal recount: menceritakan kembali pengalaman di mana penulis telah terlibat secara langsung; (2) factual recount: menceritakan kembali kejadian atau insiden seperti berita koran, laporan kecelakaan ; dan (3) imaginative recount: menceritakan peran yang bersifat imajinatif dan menghubungkan kejadian khayalan (Emilia dkk, 2008:16).

Organisasi recount text biasanya dimulai dengan orientation yang memasukkan unsur-unsur informasi latar belakang untuk membantu pembaca memahami cerita. Biasanya ada penjelasan mengenai siapa, kapan, di mana, dan mengapa yang biasanya ditulis dalam paragraf pertama. Selanjutnya diikuti dengan kejadian yang bertentangan dengan (complication) yang dijelaskan.

Tabel 1. Generic/Schematics Structure of Recount Text

\begin{tabular}{|l|l|}
\hline Generic Structure & Function Structure/Scematic \\
\hline Orientation & Mengenalkan siapa, kapan dan dimana \\
\hline Events & Peristiwa atau urutan kejadian \\
\hline Re-Oreientation & Kesimpulan \\
\hline
\end{tabular}

Recount text memiliki tata bahasa dalam penulisannya seperti penggunaan past tense, adverb of sequence time (kata keterangan urutan waktu) seperti:first, then, next, finally, etc.; memakai personal pronoun (pronomina) seperti: he, we, they, etc. (Fadlun, 2011:98). Menurut Anderson \& Anderson (1997) terdapat dua ciri recount text, yaitu sebagai berikut:

1) Menggunakan descriptive words untuk menggambarkan detail mengenai siapa, apa, kapan, di mana dan bagaimana.

2) Menggunakan proper noun untuk mengidentifikasi mereka yang terlibat di dalam recount.

\section{METODE PENELITIAN}

\section{Lokasi Waktu dan Sumbyek Penelitian}

a) Lokasi Penelitian

Penelitian ini dilakukan di SMAN 4 Kota Bima.

b) Waktu Penelitian 
Penelitian dilaksanakan dalam 2 (dua) siklus. Siklus I dari tanggal 24 Maret 2020 sampai dengan tanggal 30 Maret 2020 dan siklus II dilaksanakan tanggal 05 April 2020 sampai dengan 13 April 2020.

c) Subyek Penelitian

Subyek penelitian adalah siswa kelas XII MIPA-1 SMAN 4 Kota Bima dengan jumlah siswa 30, terdiri dari 14 orang laki-laki dan 16 orang perempuan.

\section{Faktor Yang diteliti}

Adapun faktor-faktor yang akan diteliti adalah:

1) Hasil belajar, diteliti sejauh mana hasil belajar siswa kelas XII MIPA-1 SMAN 4 Kota Bima khususnya pada keterampilan menulis (writing skill)

2) Kinerja guru, diteliti sejauh mana ketuntasan guru dalam melaksanakan dan menyelesaikan Rencana Pelaksanaan Pembelajaran.

\section{Desain Prosedur Perbaikan Pembelajaran}

\section{Gambaran Umum Penelitian}

1) Data dan Cara Pengambilannya

a) Sumber data: sumber data penelitian ini adalah seluruh siswa kelas XII MIPA-1 SMAN 4 Kota Bima serta anggota peneliti.

b) Jenis data:

- Data kualitatif terdiri dari:

1. Teacher's note (Rencana Pelaksanaan Pembelajaran)

2. Data hasil observasi pelaksanaan pembelajaran dan activitas siswa.

3. Jurnal tim peneliti

- Data Kuantitatif

1. Nilai pos tes

c) Teknik Pengambilan data

a) Data kualitatif diambil dari teacher's note (Rencana Pelaksanaan Pembelajaran) yang disusun peneliti.

b) Data tentang refleksi diri diambil dari jurnal yang dibuat oleh peneliti.

c) Data kuantitatif diambil dari skor nilai tes siswa.

\section{Indikator Kinerja}

1. Prestasi belajar siswa, rata-rata nilai post test yakni $\geq 75$.

2. Prosentase ketuntasan belajar siswa $\geq 85 \%$

3. Kinerja Guru, ketuntasan guru dalam menyelesaikan Rencana Pelaksanaan Pembelajaran dalam APKG I $\geq 91.00$.

4. Kinerja Guru, ketuntasan guru dalam Pelaksanaan Pembelajaran dalam APKG II $\geq 91.00$

\section{Intrumen Penelitian}

(a) Instrumen penelitian berupa pos tes.

(b) Lembar observasi kinerja guru.

\section{Deskripsi Per Siklus}

\section{Siklus Penelitian}

@2021 JPPI (https://jurnal.bimaberilmu.com/index.php/jppi) 
Siklus penelitian dilaksanakan dalam dua siklus. Tiap siklus terdiri dari 4 (empat) tahapan utama yakni: perencanaan; implementasi tindakan; observasi dan refleksi. Hasil refleksi akan menentukan apakah PTK dalam siklus tersebut berhasil atau belum berhasil. Jika belum berhasil maka akan dilanjutkan pada siklus berikutnya.

\section{Rincian Prosedur Penelitian}

\section{Siklus Pertama}

Tahap-tahap Perbaikan Tindakan Siklus pertama

\section{a) Perencanaan}

Dalam tahap perencanaan ini kegiatan pokok yang dilakukan adalah:

- Menyusun jadwal perbaikan

- Menyiapkan instrument pengamatan perbaikan

- Menyusun Rencana Pembelajaran (RPP) dengan mengacu pada langkah-langkah pembelajaran PPP (presentation, practice and production).

- Mempersiapkan materi pembelajaran

b) Pelaksanaan Tindakan

Melaksanakan Pembelajaran dengan mengacu pada penataan Skenario Pembelajaran yang termuat dalam Rencana Pelaksanaan Pembelajaran dengan langkah-langkah penerapan pembelajaran PPP (presentation, practice and production).

\section{c) Observasi}

Dalam observasi ini peneliti mengobservasi seluruh rangkaian kegiatan proses pembelajaran apakah dapat berjalan seperti yang direncanakan atau tidak apakah model pembelajaran PPP (presentation, practice and production) berjalan dengan baik atau tidak. Di sini peneliti dan observer melakukan pencatatan item-item kegiatan yang secara signifikan mempengaruhi proses pembelajaran, baik yang berpengaruh positif maupun negatif. Obyek observasi meliputi aktivitas guru, siswa, serta efektivitas media yang digunakan. Observer juga menggunakan lembar observasi dengan mengisi item-item butir observasi yang telah dipersiapkan.

Dalam observasi ini akan menentukan ketercapaian indikatorindikator utama yang menjadi tolok ukur keberhasilan perbaikan ini, termasuk kemampuan guru dalam melaksanakan dan menyelesaikan Rencana Pelaksanaan Pembelajaran (RPP) dengan langkah pembelajaran Bahasa Inggris mengacu pada pembelajaran PPP (presentation, practice and production). Dalam observasi menggunakan intrumen APKG PKP 2, yang dikonversi dari nilai rentangan $0-5$ menjadi $0-100$ untuk memudahkan analisis data, dilengkapi dengan catatan-catatan khusus selam proses pembelajaran, akan memberikan gambaran yang jelas tentang jalannya proses perbaikan pembelajaran.

d) Refleksi

Langkah refleksi tentu awali dengan menganalisa hasil observas, merenungkan kembali apa yang telah peneliti lakukan. Kegiatan refleksi ini bertujuan untuk: 
a) Mengetahui dan menyimpulkan langkah-langkah manakah yang dapat berjalan seperti yang direncanakan.

b) Mengetahui dan menyimpulkan langkah-langkah manakah yang tidak dapat berjalan seperti yang direncanakan.

c) Mengetahui dan menimpulkan indikator manakah yang sudah tercapai dan indikator mana yang belum tercapai.

d) Yang paling penting adalah menentukan perbaikan pembelajaran pada siklus selanjutnya (siklus kedua). Perbaikan ini dapat mencakup aspekaspek:

(1) Pengelolaan kelas

(2) Penataan skenario pembelajaran

(3) Desain tes

(4) Desain media pembelajaran

(5) Dan temuan-temuan lainnya.

(6) Keberhasilan guru dalam menerapkan model pembelajaran PPP (presentation, practice and production).

\section{Siklus Kedua}

Kegiatan pada siklus kedua merupakan rangkaian kegiatan yang tidak terpisahkan dengan kegiatan siklus pertama. Langkah-langkah kegiatan siklus kedua tidak jauh berbeda dengan siklus pertama. Yang membedakan pada siklus II telah direncanakan langkah-langkah pembelajaran hasil refleksi siklus I. Langkah-langkah sisklus II adalah: perencanaan, penerapan tindakan, observasi dan refleksi.

\section{Teknik Pengumpulan dan Analisis Data}

\section{Teknik dan Alat Pengumpulan Data}

\section{a. Tehnik Analisa Data}

1) Tehnik Pengumpulan Data

Teknik pengumpulan data kualitatif diambil melalui dokumentasi dan tes. Sedangkan pengumpulan data kuantitatif diambil melalui tes. Penjelasan tehnik pengumpulan data sebagai berikut :

a) Dokumentasi

Metode dokumentasi yaitu mencari data mengenai hal-hal atau variable yang berupa catatan lapangan, transkip, buku, surat kabar, majalah, prasasti, notulen rapat, agenda, dan sebagainya (Arikunto, 2002).

Studi dokumentasi dilakukan untuk memperkuat data yang di peroleh dalam observasi. Dokumen yang di gunakan dalam penelitian ini berupa LKS dan daftar nilai siswa.

b) Tes

Tes adalah serentetan pertanyaan atau latihan serta alat lain yang digunakan untuk mengukur keterampilan, pengetahuan inteligensi, kemampuan atau bakat yang dimiliki oleh individu atau kelompok (Arikunto, 2002). Tes dapat digunakan untuk mengukur kemampuan dasar dan pencapaian atau hasil belajar. Tes diberikan kepada siswa untuk mengetahui kemampuan kognitif siswa. Tes ini dikerjakan siswa secara individual setelah memsiswai suatu materi. Tes ini dilaksanakan pada saat proses pembelajaran melalui LKS dan tes akhir pembelajaran pada siklus I, siklus II. 


\section{b. Teknik Analisis Data}

Data-data yang diperlukan dalam penelitian ini diperoleh melalui observasi pengolahan metode pembelajaran diskusi, observasi aktivitas siswa dan guru, dan tes formatif.

Untuk mengetahui keefektifan suatu metode dalam kegiatan pembelajaran perlu diadakan analisa data. Pada penelitian ini menggunakan teknik analisis deskriptif kuantitatif, yaitu suatu metode penelitian yang bersifat menggambarkan kenyataan atau fakta sesuai dengan data yang diperoleh dengan tujuan untuk mengetahui prestasi belajar yang dicapai siswa juga untuk memperoleh respon siswa terhadap kegiatan pembelajaran serta aktivitas siswa selama proses pembelajaran.

Untuk menganalisis tingkat keberhasilan atau persentase keberhasilan siswa setelah proses belajar mengajar setiap putarannya dilakukan dengan cara memberikan evaluasi berupa soal tes tertulis pada setiap akhir putaran.

Analisis ini dihitung dengan menggunakan statistik sederhana yaitu:

a) Menilai tes formatif

Peneliti melakukan penjumlahan nilai yang diperoleh siswa, yang selanjutnya dibagi dengan jumlah siswa yang ada di kelas tersebut sehingga diperoleh rata-rata tes formatif dapat dirumuskan: Rata-rata Nilai Siswa

Rata $=\frac{\sum \mathrm{x}}{\sum \mathrm{n}}$

Keterangan $\quad \begin{aligned} \sum \mathrm{x} & =\text { Jumlah Nilai Siswa } \\ \sum \mathrm{n} & =\text { Jumlah Siswa }\end{aligned}$

b) Ketuntasan belajar

Ketuntasan belajar siswa dinyatakan tuntas belajar bila telah mencapai hasil/ nilai sesuai KKM 75 untuk pembelajaran Bahasa Inggris.

Dinyatakan tuntas belajar bila dikelas tersebut telah mencapai $85 \%$ dari KKM.

Hasil perhitungan dikonsultasikan dengan Kriteria

Ketuntasan Minimal (KKM) belajar yang dikelompokkan kedalam 2 kategori yaitu tuntas dan tidak tuntas sebagai berikut:

Tabel 2 Kriteria Ketuntasan Minimal Belajar

\begin{tabular}{|c|c|}
\hline Kriteria ketuntasan & Kualifikasi \\
\hline$\geq 75$ & Tuntas \\
\hline$<75$ & Tidak Tuntas \\
\hline
\end{tabular}

(Depdikbud. 2007: 11)

Data kualitatif, dianalisis dengan dilakukan proses koding untuk mengorganisir data. Hasil perhitungan dikonsultasikan dengan tabel kriteria penilaian kualitatif yang dikelompokkan dalam empat kategori, yaitu baik sekali, baik, cukup, kurang, kurang sekali.

\section{HASIL DAN PEMBAHASAN}

\section{Hasil dan Pembahasa Per Siklus}

Siklus Pertama (I) 
a. Perencanaan:

Dalam perencanaan ini peneliti mengkaji dengan karakteristik materi pembelajaran yakni menulis recount text, dimana recount text memiliki ciri khas tersendiri sebagaimana dikemukakan pada BAB II, yakni teks yang menceritakan kejadian yang lampau. Rangkaian pada tahapan menulis (wrinting), peneliti melakukan langkah-langkah pembelajaran kunci sebagai berikut:

\section{Presentation}

\section{a. Warmer (Pendahuluan dengan pemanasan)}

Bagian ini dimaksudkan untuk menyiapkan siswa dalam mempelajari recount text. Oleh karena itu, aktivitas pembelajaran pada bagian ini perlu mulai diarahkan pada ciri-ciri recount text.

\begin{tabular}{|l|c|}
\hline \multicolumn{1}{|c|}{ PROSEDUR } & $\begin{array}{c}\text { INSTRUKSI/ } \\
\text { CATATAN }\end{array}$ \\
\hline Hangman & Siswa menebak \\
\hline $\begin{array}{l}\text { - Guru mengajak siswa mencoba melakukan } \\
\text { permainan tebak kata. Setelah siswa mengerti dan } \\
\text { dapat melakukan aktivitas, maka aktivitas dimulai. }\end{array}$ & \\
\hline - $\begin{array}{l}\text { Kata yang ditebak: Habibie, Parepare, Ainun, } \\
\text { Germany, Dirgantara, minister, Vice President, } \\
\text { President. }\end{array}$ & \\
\hline - Guru mendeskripsikan kata dalam kalimat & \\
\hline - Siswa menebak kata dengan kata yang disiapkan & \\
\hline
\end{tabular}

\section{b. (vocabulary builder)}

Bagian ini menyajikan daftar kosakata yang dipakai dalam recount text yang akan dipelajari siswa. Dengan mempelajari kosakata yang terkait dengan teks, siswa dapat mengenali ciri-ciri kebahasaan recount text.

\begin{tabular}{|l|l|}
\hline \multicolumn{1}{|c|}{ PROSEDUR } & \multicolumn{1}{c|}{\begin{tabular}{c}
\multicolumn{1}{|c|}{ INSTRUKSI/ } \\
CATATAN
\end{tabular}} \\
\hline $\begin{array}{l}\text { - Guru meminta siswa untuk } \\
\text { menjodohkan kosakata berbahasa } \\
\begin{array}{l}\text { Inggris dengan arti katanya dalam } \\
\text { bahasa Indonesia. }\end{array}\end{array}$ & $\begin{array}{l}\text { Match the English words } \\
\text { with the Indonesian equivalents. } \\
\text { Pay attention to the parts of } \\
\text { speech. }\end{array}$ \\
\cline { 1 - 1 } $\begin{array}{l}\text { Guru meminta siswa untuk } \\
\text { mencocokkan pekerjaannya dengan } \\
\text { pekerjaan teman di sebelahnya. }\end{array}$ & $\begin{array}{l}\text { Catatan: } \\
\text { Guru juga dapat meminta siswa } \\
\text { untuk mengubah kata- } \\
\text { kata tersebut dalam kelompok } \\
\text { kata yang berbeda. }\end{array}$ \\
\hline
\end{tabular}




\section{c. Reading}

\begin{tabular}{|l|l|}
\hline \multicolumn{1}{|c|}{ PROSEDUR } & INSTRUKSI/ CATATAN \\
\hline $\begin{array}{l}\text { Task 1: Form Completion } \\
\text { Guru meminta siswa membaca bacaan } \\
\text { sambil mengisi form yang ada dalam } \\
\text { Task 1. }\end{array}$ & $\begin{array}{l}\text { Now, it's time to read } \\
\text { about Habibie. Read } \\
\text { carefully and then fill in } \\
\text { the form. }\end{array}$ \\
\hline $\begin{array}{l}\text { Task 2: Comprehension } \\
\text { Questions } \\
\begin{array}{l}\text { Guru minta siswa menjawab pertanyaan } \\
\text { dalam Comprehension Questions. }\end{array}\end{array}$ & $\begin{array}{l}\text { Answer the questions } \\
\text { based on the text. }\end{array}$ \\
\hline
\end{tabular}

\section{Practice}

\section{a. Text Structure (Think-Pair-Share)}

\section{PROSEDUR}

- Guru bertanya kepada siswa tentang struktur dalam bacaan.

- Guru lalu menggaris bawahi jawaban siswa atau menjelaskan struktur teks dalam surat secara umum interaksi pengandaian diikuti oleh perintah/saran.

- Guru meminta siswa untuk mengidentifikasi tujuan dan detil struktur bacaan yang sudah dibaca dengan cara melengkapi tabel yang tersedia dalam Task 1 . Siswa bekerja secara individu.

- Dalam Task 2, guru meminta siswa mendiskusikan hasil pekerjaannya dengan teman terdekat (pair-work). Seluruh siswa lalu mendiskusikan struktur teks secara klasikal.

\section{GRAMMAR REVIEW}

Bagian ini menyajikan tatabahasa yang digunakan dalam interaksi pengandaian diikuti oleh perintah/saran. Dengan mempelajari tatabahasa yang terkait dengan teks, siswa dapat mengenali ciri-ciri kebahasaan interaksi pengandaian diikuti oleh perintah/saran.

\section{PROSEDUR}

- Guru meminta siswa melihat kalimat di dalam kotak dan memperhatikan bentuk kata kerjanya.

- Guru membimbing siswa untuk mengenali kalimat dalam Simple Past tense yang menggunakan regular dan irregular verbs.

- Guru meminta siswa membuat kalimat dengan kata kerja yang disebutkan. Sebagai variasi, guru bisa membuat potongan- potongan kartu yang bertuliskan kata kerja tersebut. Satu kartu satu kata kerja sebanyak 4 set. Siswa dibagi dalam 4 kelompok. Masing-masing kelompok mendapatkan 1 set kartu. Kartu diletakkan menghadap ke bawah. Setiap siswa secara bergiliran mengambil satu kartu dan membuat kalimat Simple Past dengan kata kerja yang ada dalam kartu.

- Guru memberi contoh mengambil satu kartu lalu membuat satu kalimat. 
IV. Production

\section{PROSEDUR}

Task 1: Independent Writing

- Guru meminta siswa untuk menuliskan tokoh idola yang telah diceritakan kepada teman.

Task 2: Peer Feedback

- Guru meminta siswa untuk bertukar tulisan dengan teman terdekat.

- Guru meminta siswa untuk memberikan feedback tertulis untuk tulisan teman.

- Guru meminta siswa untuk memberikan feedback lisan untuk tulisan teman dan mendiskusikannya dengan teman.

\section{Task 3: Rewrite the biographical recount}

- Guru meminta siswa untuk memperbaiki tulisannnya dengan memperhatikan saran dari teman. Guru bisa memberikannya sebagai PR.

b. Pelaksanaan:

\section{Presentation}

\section{a. Warmer (Pendahuluan dengan pemanasan)}

Bagian ini dimaksudkan untuk menyiapkan siswa dalam mempelajari interaksi pengandaian diikuti oleh perintah/saran;. Oleh karena itu, aktivitas pembelajaran pada bagian ini perlu mulai diarahkan pada ciri-ciri interaksi pengandaian diikuti oleh perintah/saran;. Pelaksanaan diawali dengan warmer (pemanasan) dimana siswa diajak dengan tebak kata berkaitan dengan teks interaksi pengandaian diikuti oleh perintah/saran;. Dalam tebak kata terrsebut guru mendeskripsikan kata dan siswa menebak kata apa yang dideskripsikan guru.

Pada tahapan ini, terdapat beberapa siswa yang tidak dapat memahami maksud kalimat yang disampaikan guru, sehingga beberrapa siswa diam. Trdapat siswa-siswa yang dengan ceekatan menjawabnya dengan tepat.

\section{b. (vocabulary builder)}

Bagian ini menyajikan daftar kosakata yang dipakai dalam interaksi pengandaian diikuti oleh perintah/saran; yang akan dipelajari siswa. Dengan mempelajari kosakata yang terkait dengan teks, siswa dapat mengenali ciriciri kebahasaan interaksi pengandaian diikuti oleh perintah/saran;.

Dalam kegiatan menjodohkan kata kegiatan sangat dinamis dimana siswa berusaha menemukan kata yang tepat. Terdapat beberapa siswa yang pasif, karena tidak tahu arti kata-kata tersebut sehingga tidak tahu appa yang harus dilakukan sambil melihat teman-temannya yang sibuk.

\section{c. Reading}

Dalam langkah ini ada 2 kegiatan pokok: 1) Guru meminta siswa membaca bacaan sambil mengisi form yang ada dalam Task one; 2) Guru minta siswa menjawab pertanyaan dalam Comprehension Questions.

Terdapat beberapa siswa yang tidak memamami sebagian beesar kosa kata pasiff, tidak dapat menyeleesaikan task 1 maupun taks 2.

\section{Practice}

\section{a. Text Structure (Think-Pair-Share)}

Dalam rangkaina kegiatan ini guru mempresentasikan struktur interaksi pengandaian diikuti oleh perintah/saran: 
Pola if clause a suggestion Pola if clause + a suggestion atau zero conditional sentence adalah: If + present tense, present tense. Pada bagian klausa utama, kita bisa menggunakan should, had better, atau ought to. Contoh if clause a suggestion: If you want to get a perfect score, you should study hard.

Secara individual siswa ditugaskan mengisi tugas berkaitan dengan bacaan dan struktur interaksi pengandaian diikuti oleh perintah/saran;.

Pada langkah ini terdapat siswa yang dapat menyelesaikan tugas dengan baik, dan terdapat 30\% siswa yang tidak dapat menyelesaikan tugasnya dengan tepat.

\section{b. Grammar Review}

Masih pada bagian dari kegiatan practice, guru menyajikan tatabahasa yang digunakan dalam interaksi pengandaian diikuti oleh perintah/saran;. Dengan mempelajari tatabahasa yang terkait dengan teks, siswa dapat mengenali ciri-ciri kebahasaan interaksi pengandaian diikuti oleh perintah/saran;

Sebagian besar siswa dapat melaksanakan pembelajaran ini dengan baik dan mengerjakan tugas dengan tepat. Pelaksanaan kegiatan ini terdapat beberapa kendala yakni keterbbatasan kosa kata. Dalam hal ini bebeerapa siswa tidak memiliki cukp kosa kata.

\section{Production}

Tahapan ini merupakan inti tahapan menulis (writing) dimana siswa ditugaskan menulis jenis interaksi pengandaian diikuti oleh perintah/saran;. Siswa ditugaskan menulis kalimat dengan struktur: Pola if clause a suggestion Pola if clause + a suggestion atau zero conditional sentence adalah: If + present tense, present tense. Pada bagian klausa utama, kita bisa menggunakan should, had better, atau ought to. Contoh if clause a suggestion: If you want to get a perfect score, you should study hard. tokoh idola masing-masiing, dengan model teks yang telah diberikan.

Rangkaian kegiatan ini berjalan dinamis dimana siswa sibuk menulis idolanya dalam bahasa Inggris. Pada kegiatan Peer Feedback 70\% siswa dapat memberikan feedback temannya dengan baik. $30 \%$ tidak tepat dalam memberikan feedback.

Pada kegiatan Rewrite yang disusun oleh masing-masing siswa dan telah diberikan feedback oleh temannya seluruh siswa mengerjakan tugas meskipun terdapat kekurangan-kekurangan

Pada kegiatan Rewrite the biographical recount yang disusun oleh masing-masing siswa dan telah diberikan feedback oleh temannya seluruh siswa mengerjakan tugas meskipun terdapat kekurangan-kekurangan khususnya dalam penyusunan kaimat yang bercampur-campur antara

c. Observasi present tense dan past tense, serta peneempatan kata kerja yang tidak sesuai.

Selanjutnya, peneliti dan kolaborator secara bersama-sama mengadakan refleksi tentang proses pembelajaran di siklus I. Adapun yang menjadi dasar pemikiran adalah catatan Guru dalam teaching log, hasil observasi, hasil karya peserta didik dalam independent consruction of the text, dan angket refleksi peserta didik siklus I. Hasil nilai sebagai berikut : 
1. Peningkatan nilai kemampuan menulis siswa

\begin{tabular}{|l|c|c|}
\hline \multicolumn{1}{|c|}{ Siklus } & $\begin{array}{c}\text { Nilai Rata- } \\
\text { Rata }\end{array}$ & $\begin{array}{c}\text { Porsentase } \\
\text { Ketuntasan }\end{array}$ \\
\hline Pra Siklus & 64.00 & $70.00 \%$ \\
\hline Siklus I & 68.00 & $75.00 \%$ \\
\hline Siklus II & 78.00 & $88.00 \%$ \\
\hline
\end{tabular}

2. Kinerja guru

\begin{tabular}{|l|c|c|}
\hline \multicolumn{1}{|c|}{ Siklus } & APKG I & APKG II \\
\hline Pra Siklus & 91.00 & 90.00 \\
\hline Siklus I & 90.90 & 90.77 \\
\hline Siklus II & 92.80 & 91.78 \\
\hline
\end{tabular}

d. Refleksi:

Teknik pembelajaran PPP (presentatiin, practice and production)

Siklus I secara umum dapat berjalan dengan baik, akan tetapi pada siklus I belum seperti yang diiharapkan. Terdapat beberrap hal yang perlu diperrbaiki pada siklus berikutnya yang menyebabkan pembelajarn tidak optimal pada siklus I yakni:

1) Guru cenderung mengejar penyelesaian materi sehingga fokus perhatian lebih banyak pada siswa-siswa yang pintar, yang memiliki kosa kata cukup. Siswa yang memiliki kosa kata terbatas kurang mendapat perhatian guru. Sehingga pemahaman siswa pada pembelajaran tidak merata

2) Guru belum menuntaskan siswa yang mengalami kesulitan dalam memahami recount text, yang kesulitan memahami struktur recount text, sehingga sampai akhir tahapan pemembelajaran siswa tidak dapat mengerjakan tugasnya dengan tepat.

3) Tugas-tugas yang diberikan terlalu banyak, sehingga siswa yang kompeteninya renndah mengalami kesulitan dan kejenuhan dalam mengikui pelajaran. Dengan demikian guru perlu menyederhanakan tugas-tugaas yanng diberikan selama proses pembelajaran.

\section{Pembahasan Siklus I}

a) Kemampuan menulis (writting) siswa

Siklus I, hasil deskripsi pots test menunjukkan bahwa prestasi belajar siswa rata-rata 68.00 meskipun nilai rata-rata ini telah mengalami peningkatan dibanding sebelum diadakan perbaikan $(+4.00)$, tetapi nilai ini belum memenuhi indikator kinerja yang ditetapkan yakni rata-rata $\geq 75$. Persentase ketuntasan $75.00 \%$, Persentase ini masih dibawah indikator kinerja yakni $\geq 85 \%$. Dari sisi prestasi belajar siklus I (pertama) belum berhasil sehingga dilanjutkan pada sikus II.

b) Kinerja Guru dalam perencanaan pembelajaran

Skor kinerja guru kompetensi guru dalam perencanaan kegiatan pembelajaran yang mendidik pada siklus I 90,90\%. Terdapat 7 deskriptor yang sebagian dilaksanakan (sebagain terpenuhi) dan 4 deskriptor seluruhnya 
dilaksanakan (seluruhnya terpenuhi). Dengan demikian dari sisi kinerja guru siklus I belum mencapai indikator kinerja yang ditetapkan yakni $\geq 92 \%$.

Skor kinerja guru kompetensi guru dalam pelaksanaan pembelajaran kegiatan pembelajaran yang mendidik pada siklus I 90,77. Terdapat 8 deskriptor yang sebagian dilaksanakan (sebagian terpenuhi) dan 3 deskriptor seluruhnya dilaksanakan (seluruhnya terpenuhi). Dengan demikian dari sisi kinerja guru siklus I belum mencapai indikator kinerja yang ditetapkan yakni $\geq 91 \%$.

c) Refleksi

Berdasarkan pada refleksi di akhir siklus I, ada beberapa hal yang dapat dicatat, diantaranya adalah:

1. Guru cenderung mengejar penyelesaian materi sehingga fokus perhatian lebih banyak pada siswa-siswa yang pintar, yang memiliki kosa kata cukup. Siswa yang memiliki kosa kata terbatas kurang mendapat perhatian guru. Sehingga pemahaman siswa pada pembelajaran tidak merata.

2. Guru belum menuntaskan siswa yang mengalami kesulitan dalam memahami recount text, yang kesulitan memahami struktur recount text, sehingga sampai akhir tahapan pemembelajaran siswa tidak dapat mengerjakan tugasnya dengan tepat.

3. Tugas-tugas yang diberikan terlalu banyak, sehingga siswa yang kompeteninya renndah mengalami kesulitan dan kejenuhan dalam mengikui pelajaran. Dengan demikian guru perlu menyederhanakan tugas-tugaas yanng diberikan selama proses pembelajaran.

\section{Pembahasan Siklus II}

a. Perencanaan

Berdasarkan refleksi dari siklus I, jumlah pertemuan dalam siklus II ditambah tetap dilaksanakan dalam 2 kali pertemuan. Teks yang diajarkan dalam siklus II ini adalah if clause interaksi pengandaian diikuti oleh perintah/saran.

b. Pelaksanaan

Dalam pelaksanaan siklus II peneliti telah mengidentifikasi kelemahankelemahan siklus I dan melaksanakan perbaikan pada langkah-langkah kunci yakni:

1) Guru tidak semata-mata mengejar penyelesaian materi saja dan tidak hanya fokus perhatian pada siswa-siswa yang pintar, yang Sehingga pemahaman siswa pada pembelajaran relatif merata kesenjangan pemahaman kosa kata struktur tidak terlalu mencolok.

2) Guru berhasil menuntaskan siswa yang mengalami kesulitan dalam memahami interaksi pengandaian diikuti oleh perintah/saran;, yang kesulitan memahami struktur interaksi pengandaian diikuti oleh perintah/saran;, sehingga sampai akhir tahapan pemembelajaran seluruh siswa tidak mengerjakan tugasnya dengan cermat.

3) Tugas-tugas yang diberikan telah disederhanakan, tidak terlalu banyak dan memperhitungkan kesiapan siswa. Siswa yang kompeteninya bisa menyesuaikan dengan pekerjaan tugas-tugas dan tidak lagi mengalami kejenuhan dalam mengikui pelajaran.

c. Observasi

1) Kemampuan menulis siswa 
Siklus II, hasil deskripsi pots test menunjukkan bahwa prestasi belajar siswa rata-rata 78,00 nilai ini mengalami peningkatan dibanding siklus I (+10.00) dengan ketuntasan belajar klasikal 88,00\% mengalami peningkatan dibanding siklus I (+13). Dengan perbaikan proses pada pembelajaran maka siklus II berhasil mencapai indikator yang ditetapkan yakni rata-rata $\geq 75$ dan persentase ketuntasan $\geq 85 \%$. Dari sisi prestasi belajar siklus II (kedua) telah berhasil.

2) Kinerja Guru dalam pelaksanaan pembelajaran

Skor kinerja guru kompetensi guru dalam perencanaan kegiatan pembelajaran yang mendidik pada siklus II 92,80\% semuanya deskriptor seluruhnya dilaksanakan (seluruhnya terpenuhi). Dengan demikian dari sisi kinerja guru siklus II berhasil mencapai indikator kinerja yang ditetapkan yakni $\geq 92 \%$.

Skor kinerja guru kompetensi guru dalam pelaksanaan pembelajaran kegiatan pembelajaran yang mendidik pada siklus II 91,78. Terdapat 1 deskriptor yang belum dilaksanakan (sebagian terpenuhi). Dengan demikian dari sisi kinerja guru siklus II berhasil mencapai indikator kinerja yang ditetapkan yakni $\geq 91 \%$.

d. Refleksi

Pada siklus II perencanaan pembelajaran dan pelaksanaan pembelajaran telah menyesuaikan hasil refleksi siklus I, sehingga pelaksanaan pembelajaran beerajalan sesudi yang direncanakan.

\section{Peningkatan Hasil Pembelajaran Menulis (writting)}

Teknik pembelajaran PPP (presentation, practice and production) apabila dilaksanakan dengan tepat, seperti yang dilakukan peneliti pada siklus II, sangat efektif untuk membuat siswa meningkatkan kemampuan dalam proses pembelajaran menulis menulis (writing) interaksi pengandaian diikuti oleh perintah/saran; Semakin sering siswa dalam melatih kemampuan menulisnya (writing) maka siswa dapat menguasai penerapan bahasa yang baik dan efektif. Ide atau gagasan yang dimiliki oleh siswa sering kali tidak muncul ketika proses berfikir karena kurang adanya umpan balik sehinggga sering kali siswa menunggu dalam waktu yang lama untuk memunculkan ide yang ada dipikiran mereka. Melalui penerapan teknik PPP (presentation, practice and production) siswa mulai membuka wawasan terhadap media yang diberikan. Hal ini dapat memotivasi siswa untuk meningkatkan kemampuan menulis (writing) interaksi pengandaian diikuti oleh perintah/saran;. Siswa dapat menuangkan ide - ide baru untuk mendekskripsikan tema menulis (writing) interaksi pengandaian diikuti oleh perintah/saran;. yang telah diberikan oleh guru. Siswa juga dapat membagi atau menyalurkan ide yang telah mereka dapatkan kepada teman sekelasnya.

Hasil pembelajaran menulis (writing) dengan mengimplementasikan menulis (writing) interaksi pengandaian diikuti oleh perintah/saran; pada siswa kelas X IPA1 menunjukkan peningkatan ppada siklus I dan siklus II. Data kuantitatif penelitian menunjukkan bahwa penerapan pendekatan (presentation, practice and production) dalam pembelajaran menulis (writing) dapat meningkatkan kemampuan peserta didik dalam menulis interaksi pengandaian diikuti oleh perintah/saran. 


\section{KESIMPULAN}

Adapun kesimpulan dari penelitian ini: 1) Penggunaan metode PPP (presentation, practice and production) dapat meningkatkan hasil belajar siswa pada mata pelajaran Bahasa Inggris materi interaksi pengandaian diikuti oleh perintah/saran; di SMAN 4 Kota Bima kelas XIII MIPA.1 semester genap tahun pelajaran 2019/2020. Penggunaan metode PPP (Presentation, Practice and Production) $u$ ntuk Meningkatkan Hasil Belajar Siswa pada Mata Pelajaran Bahasa Inggris Materi Interaksi pengandaian diikuti oleh perintah/saran; di SMAN 4 Kota Bima Kelas XII MIPA 1 Semester Genap Tahun Pelajaran 2019/2020; 2) Penggunaan metode PPP (presentation, practice and production) dapat meningkatkan kinerja guru Bahasa Inggris.

Kemudian saran dan tindak lanjut dari hasil penelitian ini: 1) Kepada guru yang melaksanakan pembelajaran Bahasa Inggris disarankan menerapkan pembelajar PPP (presentation, practice and production) dalam meningkatkan kemampuan menulis (writing) interaksi pengandaian diikuti oleh perintah/saran;; 2) Kepada guru, disarankan untuk memperhatikan rambu-rambu yang dimuat dalam Permendikbud Nomor 22 Tahun 2016 tentang standar proses dan buku pegangan pembelajaran guru, khususnya dalam mendesain RPP, melaksanakan pembelajaran, serta mendesain pertanyaan-pertanyaan yang akan disajikan dalam pembelajaran agar pembelajaran sesuai dengan PPP (presentation, practice and production), sekaligus sesuai dengan pembelajaran Kurikulum 2013; 3) Kepada guru disarankan agar terus menggali dan mengembangkan genre based dalam praktek pembelajaran, sehingga pembelajaran PPP (presentation, practice and production) bukan hanya sekedar konsep teoritis, tapi benar-benar dapat dilaksanyakan secara nyata di kelas dan menunjukkan efektivitasnya; 4) Kepada Kepala Sekolah disarankan untuk proaktif memotivasi guru agar secara kontinyu memperbaiki pembelajaran, memanfaatkan hasil peneltian guru guna peningkatan kualitas pembelajaran di sekolah; dan 5) Kepada instansi terkait, disaraankan untuk memberikan apresiasi yang tinggi dan kepada guru-guru yang telah melakukan inovasi pembelajaran. Apresiasi tersebut dapat berupa bantuan finansial untuk pengembangan inovasi pembelajaran guru lebih lanjut.

\section{DAFTAR PUSTAKA}

Ahmadi, Abu dan Munawar Sholeh. (2005). Psikologi Perkembangan. Jakarta: Rineka Cipta.

Anderson, M. \& Anderson, K. (1997). Text Types in English 1. Melbourne: Macmillan Education Australia.

Atkinson, D. (2003). L2 menulis (writting) in the post-process era: Introduction. Journal of Second Language Menulis (writting), 12 (1), 3-15.

Busono, G. A. (2016). Pengaruh Sistem Pelatihan Dan Pengembangan Karyawan Terhadap Kinerja Karyawan Pt. Persada Sawit Mas (PSM) Kecamatan Pampangan Kabupaten Ogan Komering Ilir.Muqtashid,1(1), 81-114.

Badger, R., \& White, G. (2000). A process genre approach to teaching menulis (writting). ELT Journal, 54 (2), 153-160. 
Collerson, J. (1988). Menulis (writting) for Life. NSW : Primary English Teaching Association.

Desmita. (2010). Psikologi Perkembangan.Bandung: PT. Remaja Rosdakarya.

DePorter, Bobbi \&Mike Hernacki. (2001). Quantum Learning. Membiasakan Belajar Nyaman dan Menyenangkan.Bandung : Penerbit Kaifa.

Depdiknas. (2003). Undang-undang RI No.20 tahun 2003.tentang sistem pendidikan nasional.

Flowerdew, John dan Lindsay Miller. (2002). Second Language Listening, Theory and Practice. USA: Cambridge University Press.

Feez, S. \& Joyce, H. (2002). Text-based Syllabus Design. Sydney, NSW : Ames.

Flowerdew, John dan Lindsay Miller. (2005). Second Language Listening, Theory and Practice. USA: Cambridge University Press.

Hamalik, Umar. (1983). Metodologi Belajar dan Kesulitan-kesulitan Belajar. Jakarta : Tarsito.

Hadi,S., Tukiran, T., \& Yuwono, B. (2009). Pengaruh Supervisi Akademik, Kompetensi Guru dan Kedisiplinan Terhadap Kinerja Guru SMA Negeri 3 Slawi Kabupaten Tegal.Khazanah Pendidikan,2(1).

Harmer, Jeremy. (2007). The Practice of English Language Teaching. New York : Longman Group Limited.

Hyland, Ken. (2003). Second Language Writing. UK: Cambridge University Press.

Harmer, J. (2001). The Practice of English Language Teaching. Cambridge : Longman.

Hyland, K. (2003a). (presentation, practice and production) pedagogies: A social response to process. Journal of Second Language Menulis (writting), 12(1), 17-29.

Hyland, K. (2003b). Second language menulis (writting). Cambridge: Cambridge university press.

Hyland, K. (2007). Genre and second language menulis (writting). USA: The university of Michigan press. Muncie, J. (2002). Process menulis (writting) and vocabulary development: comparing Lexical frequency orofiles across drafts. System, 30(2), 225-235.

Joni, Raka. (1980). Strategi Be/ajar Mengajar. Jakarta: P2TK Ditjen Dikti.

Kementerian Pendidikan Nasional. Direktorat Jenderal Peningkatan Mutu Pendidik dan Tenaga Kependidikan. (2010). Pedoman Pelaksanaan Penilaian Kinerja Guru(PK Guru). Jakarta. www.bermutuprofesi.org.

Kartowagiran, B. (2011). Kinerja Guru Profesional (Guru Pasca Sertifikasi).Jurnal Cakrawala Pendidikan,3(3).

Minarsih, M. M. (2015). Analisis Pengaruh Kepemimpinan Transformasional, Moral Dan Komitmen Organisasi Terhadap Organizational Citizenship Behavior 
Dalam Meningkatkan Kinerja Guru Sekolah Dasar Swasta di Kecamatan Pedurungan Kota Semarang.Jurnal Ekonomi dan Bisnis Kontemporer,1(01).

Nuchiyah, Nunu. (2007). Pengaruh Kepemimpinan Kepala Sekolah dan Kinerja Mengajar Guru Terhadap Prestasi Belajar Siswa. Jurnal Pendidikan Dasar. Vol.5 no.7: $1-4$.

Pollard, Lucy. (2008). A Guide to Teaching English. New York : All Rights Reserved.

Paltridge, B. (2002). Genre, text type, and the English for Academic Purposes (EAP). In A.M. Johns (Ed.), Genre in the classroom:multiple perspectives. Marwah, N.J: L.Erlbaum, pp. 73-90

Paltridge, B. (1996). Genre, text type, and the language learning classroom. ELT Journal, 50(3), 237-243.

Paltridge, B. (2000). Genre analysis. In B. Paltridge (Ed), Making sense of discourse analysis. Gold Coast, QLD: Antipodean Educational Enterprises, pp. 105-126

Paltridge, B. (2001). Genre and the language learning classroom. Ann Arbor: University of Michigan Press.

Paltridge, B. (2007). Approaches to Genre in ELT. In J. Cummins, \& C. davison (Eds.), International handbook of English Language Teaching, Vol. 15, 931-943. Springer US.

Suryabrata Sumadi, Psikologi Pendidikan, (Jakarta : Rajawali, 1980).

Santrock, J. W. (1998). Perkembangan Remaja. Jakarta: Erlangga.

Sukardi, (2004), Metodologi Penelitian Pendidikan: Kompetensi dan Praktiknya, Jakarta: Bumi Aksara.

Slameto, (1991). Proses Belajar Mengajar Dalam Sistem Kredit Semester (SKS).Jakarta: Bumi Aksara.

White, R and Arndt, V. (1991). Process Menulis (writting). Pearson Education, Ltd. Vygotsky, L. (1978). Mind in society and the ZPD. USA: Harvard. 